\title{
The Resilience Of Cuprous Oxide Under Oxidizing Thermal Treatments Via Magnesium Doping
}

\author{
João Resende ${ }^{*}, 1,2$, Odette Chaix-Pluchery ${ }^{1}$, Mauro Rovezzi ${ }^{3}$, Yoann Malier ${ }^{2}$, Hubert \\ Renevier $^{1}$, Ngoc Duy Nguyen ${ }^{2}$, Jean-Luc Deschanvres ${ }^{1}$ and Carmen Jiménez ${ }^{1}$ \\ ${ }^{1}$ Univ. Grenoble Alpes, CNRS, Grenoble INP, LMGP, F-38000 Grenoble, France \\ 2 Département de Physique, CESAM/Q-MAT, SPIN, Université de Liège, B-4000 Liège, \\ Belgium \\ ${ }^{3}$ Univ. Grenoble Alpes, CNRS, IRD, Irstea, Météo France, OSUG, FAME, 38000 Grenoble, \\ France
}

Corresponding author: Jean-Luc Deschanvres (jean-luc.deschanvres@ grenoble-inp.fr)

\begin{abstract}
This study reports the influence of the magnesium incorporation into cuprous oxide $\left(\mathrm{Cu}_{2} \mathrm{O}\right)$ on its transformation in cupric oxide $(\mathrm{CuO})$. Thermal treatments under oxidizing conditions are performed on undoped and magnesium-doped cuprous oxide thin films, $\mathrm{Cu}_{2} \mathrm{O}$ and $\mathrm{Cu}_{2} \mathrm{O}: \mathrm{Mg}$ respectively, deposited by aerosol-assisted metal organic chemical vapour deposition. The oxidation kinetics of these films shows a slower rate in the $\mathrm{Cu}_{2} \mathrm{O}: \mathrm{Mg}$ system, since the complete oxidation into $\mathrm{CuO}$ occurs at a higher temperature when compared to undoped $\mathrm{Cu}_{2} \mathrm{O}$. The increased stability of $\mathrm{Cu}_{2} \mathrm{O}: \mathrm{Mg}$ can be explained by the inhibition of the formation of split copper vacancies, the defect most frequently associated with the $\mathrm{CuO}$ nucleation. Annealing treatments performed on $\mathrm{Cu}_{2} \mathrm{O}$ thin films provide new insights on the dopant influence on the mechanism to generate simple and split copper vacancies as well as the transformation of $\mathrm{Cu}_{2} \mathrm{O}$ into $\mathrm{CuO}$.
\end{abstract}

\section{Introduction}

Cuprous oxide, $\mathrm{Cu}_{2} \mathrm{O}$, is considered as a suitable oxide material for all-oxide photovoltaic applications ${ }^{1,2}$ due to its direct bandgap of $2.17 \mathrm{eV}$ and intrinsic p-type semiconducting behaviour. ${ }^{3}$ The main mechanism for the p-type conduction of cuprous oxide is the generation of copper vacancies, $V_{C u}^{\prime}{ }^{4}$ considered as the preferential defect for the creation of holes when compared to oxygen interstitials, $O_{i}^{\prime \prime}$. These copper vacancies can be formed by the oxidation of $\mathrm{Cu}_{2} \mathrm{O}$, which leads to a displacement of a $\mathrm{Cu}$ atom, leaving a negatively charged vacancy. As a consequence, a hole is introduced in the valence band, creating an acceptor level between 0.2 and $0.6 \mathrm{eV}$ above this band., 
However, the exact nature of this level is not yet completely understood. Indeed, two types of copper vacancies can exist in $\mathrm{Cu}_{2} \mathrm{O}$ : the simple copper vacancy, $V_{C u}^{\prime}$, related to the removal of one $\mathrm{Cu}$ atom, resulting in two $\mathrm{O}$ atoms coordinated by three $\mathrm{Cu}$ neighbours, or the split copper vacancy $V_{C u}^{\text {split }}$ in which the $\mathrm{Cu}$ exit is followed by a displacement of a neighbouring $\mathrm{Cu}$ atom towards the vacancy. In the latter case, the $\mathrm{Cu}$ atom moves into a tetrahedral site with four neighbouring $\mathrm{O}$ atoms around. This four-fold $\mathrm{Cu}$ coordination is similar in $\mathrm{CuO}$. This split vacancy also promotes the generation of a highly localized hole, which can lead to change the oxidation state of the shifted $\mathrm{Cu}$ atom, from $\mathrm{Cu}^{+}$to $\mathrm{Cu}^{2+}$.

The creation of these two copper vacancies in $\mathrm{Cu}_{2} \mathrm{O}$ films is frequently reported in literature after post-deposition annealing treatments under oxidizing conditions. ${ }^{8-10}$ At temperatures below $300^{\circ} \mathrm{C}, \mathrm{Cu}_{2} \mathrm{O}$ thin films show a resistivity decrease to values as low as 100 $\Omega . c m$, due to an increase of the p-type charge carrier concentration which can reach up to $10^{16}$ $\mathrm{cm}^{-3} .8,11$ Nevertheless, the use of high temperature treatments in oxygen atmosphere also promotes the transition from $\mathrm{Cu}_{2} \mathrm{O}$ thin films into cupric oxide $\mathrm{CuO},{ }^{8-10,12}$ which starts at temperatures ranging from 250 to $350{ }^{\circ} \mathrm{C}$. The cupric oxide phase presents a bandgap of 1.35 $\mathrm{eV}$ at room temperature, ${ }^{13}$ which leads to a darkening of the films. ${ }^{10}$ The conversion of $\mathrm{Cu}_{2} \mathrm{O}$ into $\mathrm{CuO}$ is attributed to the diffusion of copper to the surface, which consequently generates copper vacancies in the bulk material, where $V_{C u}^{\text {split }}$ sites are suggested as nucleation centres for $\mathrm{CuO} .{ }^{6}$ Additionally, a direct oxidation of $\mathrm{Cu}^{+}$to $\mathrm{Cu}^{2+}$ at the surface of the films can promote the formation of $\mathrm{CuO}$, when exposed to moisture and under solar limitation. ${ }^{14}$ Recent studies report the generalization of the presence of $\mathrm{CuO}$ at the grain boundaries of $\mathrm{Cu}_{2} \mathrm{O}$, when deposited by different techniques, leading to a reduction of the electrical performances of cuprous oxide for solar cells applications. ${ }^{15-17}$ In a study of all-oxide solar cells, both types of copper-based oxides were compared as photovoltaic p-type absorbing layer, combined with $\mathrm{ZnO}$ as n-type counterpart. ${ }^{18}$ For the $\mathrm{CuO}$ case, a short-circuit current density $\left(J_{S C}\right)$ below 0.5 $\mathrm{mA} . \mathrm{cm}^{2}$ is obtained, due to a high series resistance, while in the $\mathrm{Cu}_{2} \mathrm{O}$ case, the $J_{S C}$ reaches 3.5 $\mathrm{mA} . \mathrm{cm}^{2}$. Still, the maximum efficiency of a functional solar cell is $4.12 \%$ and a maximum short-circuit current density of $11.42 \mathrm{~mA} . \mathrm{cm}^{2}$ for an intrinsic $\mathrm{ZnO} / \mathrm{Cu}_{2} \mathrm{O}$ junction. ${ }^{19,20}$ The use of dopants was suggested as a way to obtain an n-type $\mathrm{Cu}_{2} \mathrm{O}$ and create homojunction solar cells with an intrinsic p-type counterpart. Fluorine-doped $\mathrm{Cu}_{2} \mathrm{O}$ thin films were integrated in a solar cell, with an efficiency still low, below $0.5 \%$, due to a low open-circuit voltage. ${ }^{21}$ Though, dopants are more commonly used to improve the p-type conductivity of $\mathrm{Cu}_{2} \mathrm{O}$, aiming for its application in high efficient all-oxide solar cells. The incorporation of sodium reduced 
drastically the resistivity of $\mathrm{Cu}_{2} \mathrm{O}$ to $10^{-2} \Omega . \mathrm{cm},{ }^{22}$ which consequently allowed an increase of $8.1 \%$ maximum efficiency in this $\mathrm{Cu}_{2} \mathrm{O}$-based solar cells, in a $\mathrm{MgF}_{2} / \mathrm{ZnO}: \mathrm{Al} / \mathrm{Zn}_{0.38} \mathrm{Ge}_{0.62} \mathrm{O} / \mathrm{Cu}_{2} \mathrm{O}: \mathrm{Na}$ heterojunction. ${ }^{23}$ This record of efficiency was achieved by thermal oxidized $\mathrm{Cu}_{2} \mathrm{O}$, which is unsuitable for industrialization of low cost solar cells, since it requires temperatures above $1000^{\circ} \mathrm{C} .{ }^{24}$ Other dopants as nitrogen ${ }^{25,26}$ and strontium ${ }^{27,28}$ reduced the resistivity values to $1 \Omega . \mathrm{cm}$ and increased the hole density up to $10^{17} \mathrm{~cm}^{-3}$ in $\mathrm{Cu}_{2} \mathrm{O}$ thin films grown by sputtering or chemical vapour deposition, respectively. The incorporation of magnesium in $\mathrm{Cu}_{2} \mathrm{O}$ likewise showed a strong effect on the resistivity, reducing it to $7 \Omega . \mathrm{cm}$ by increasing the charge carrier density up to $8.1 \times 10^{17} \mathrm{~cm}^{-3} \cdot{ }^{29}$ Theoretical studies propose the use of magnesium as a $\mathrm{Cu}_{2} \mathrm{O}$ dopant in order to change the direct band-gap and the vacancy formation in the material. ${ }^{6,30}$ Magnesium-doped $\mathrm{Cu}_{2} \mathrm{O}$ was already used to create solar cells using $\mathrm{TiO}_{2}$ as n-type semiconductor ${ }_{-31}^{31}$ in this case, the presence of the dopant increased the photo-conductivity of cuprous oxide by reducing the formation of split vacancies. However, the thermal stability of $\mathrm{Cu}_{2} \mathrm{O}: \mathrm{Mg}$ films was not evaluated after post-annealing treatments.

In this study, $\mathrm{Cu}_{2} \mathrm{O}$ and $\mathrm{Mg}$-doped $\mathrm{Cu}_{2} \mathrm{O}$ thin films were thermally annealed in air at temperatures ranging from $250{ }^{\circ} \mathrm{C}$ to $500{ }^{\circ} \mathrm{C}$. We analysed the effect of $\mathrm{Mg}$ incorporation on the stability of the $\mathrm{Cu}_{2} \mathrm{O}$ phase and on the formation of the $\mathrm{CuO}$ parasitic phase via the analysis of the morphology and structural properties of the films.

\section{Experimental}

\subsection{Film deposition}

A butanol-based solution containing the precursor was used for the deposition by Aerosol-Assisted Metal Organic Chemical Vapour Deposition (AA-MOCVD or AACVD). The total concentration of the solution was fixed at $30 \mathrm{mM}$ in all cases. The first solution was composed of pure copper acetylacetonate, $\mathrm{Cu}(\mathrm{acac})_{2}$ [Sigma Aldrich], while in the second one magnesium acetylacetonate, $\mathrm{Mg}(\mathrm{acac})_{2}$ [Sigma Aldrich], was added to the solution. The $\mathrm{Mg} /(\mathrm{Mg}+\mathrm{Cu})$ concentration ratio in the later solution was fixed at $33 \%$ at to produce sufficiently low resistivity materials as seen in our previous study. ${ }^{29}$ Ethylendiamine $\left[\mathrm{C}_{2} \mathrm{H}_{8} \mathrm{~N}_{2}\right.$, Sigma Aldrich] with a concentration of $40 \mathrm{mM}$ was added to increase the solubility of the chemical precursor. The temperature of the substrates, Corning glass 1737 and p-type silicon wafer, was fixed at $350^{\circ} \mathrm{C}$. The deposition time was 3 hours and the solution consumption rate was 1.5 $\mathrm{mL} \cdot \mathrm{min}^{-1}$ with an Argon flow of $6 \mathrm{~L} \cdot \mathrm{min}^{-1}$ and $\mathrm{O}_{2}$ flow of $2.5 \mathrm{~L} \cdot \mathrm{min}^{-1}$, resulting in an $\mathrm{O}_{2}$ content of $29 \%$.

Supprimé: , grown in these cases

Mis en forme : Indice

Supprimé: ies

Supprimé:

Supprimé: which 
The study of the stability of the grown films under thermal annealing was performed on a hot-plate exposed to air. Three temperature $\left(\mathrm{T}_{\mathrm{a}}\right)$ were chosen for the annealing treatment: 250 ${ }^{\circ} \mathrm{C}, 350^{\circ} \mathrm{C}$ and $450^{\circ} \mathrm{C}$, all for 30 minutes, while the heating and cooling rates were kept constant at $10^{\circ} \mathrm{C} / \mathrm{min}$. One additional annealing treatment at $500{ }^{\circ} \mathrm{C}$ for 30 minutes was specially performed for the XANES and EXAFS film analysis.

\subsection{Characterization techniques}

Grazing incidence X-ray diffraction (GI-XRD) patterns were collected using a Bruker D8 Advance diffractometer and the $\mathrm{Cu} \mathrm{K}_{\alpha 1}$ radiation with an incidence angle of $0.5^{\circ}$. This configuration in grazing incidence was used for higher sensitivity with respect to phases present in lower proportions, compared with the more standard Bragg-Brentano configuration. Raman spectroscopy was carried out at room temperature with a Jobin Yvon/Horiba LabRam spectrometer equipped with a liquid nitrogen-cooled charge-coupled device detector. The spectra were collected in the 50 to $1800 \mathrm{~cm}^{-1}$ frequency range. The $488 \mathrm{~nm}$ blue line of an $\mathrm{Ar}^{+}$ laser was used as the exciting line with a power of $0.4 \mathrm{~mW}$ at the sample surface. The laser was focused to a spot size close to $1 \mu \mathrm{m}^{2}$ by using a 100x objective. Scanning Electron Microscopy (SEM) and Energy-dispersive X-ray spectroscopy (EDS) were conducted in a FEI Quanta 250 FE-ESEM tool, with an energy beam of $5000 \mathrm{eV}$ to quantify the different elements in the film. The $\mathrm{Cu} \mathrm{L} \alpha$ and $\mathrm{Mg} \mathrm{K} \alpha$ lines occur at $930 \mathrm{eV}$ and $1253 \mathrm{eV}$ in the EDS spectra, respectively. Cross-section images were used to measure the film thickness. X-ray photoelectron spectroscopy (XPS) was performed using a K-alpha spectrometer, from Thermo Scientific, with an $\mathrm{Al} \mathrm{K \alpha 1,2}(1486.6 \mathrm{eV}) \mathrm{X}$-ray source, analysing $\mathrm{Cu} 2 \mathrm{p}$ peak between $925 \mathrm{eV}$ to $965 \mathrm{eV}$. The X-ray Absorption Spectroscopy (XAS) was conducted at the French CRG "FAME" beamline, BM30B at the European Synchrotron Radiation Facility (ESRF), obtaining the spectra at the $\mathrm{Cu}$ K-edge $(89789 \mathrm{eV})$. Athena software enabled the treatment of the raw data for both X-ray Absorption Near Edge Structure (XANES) and Extended X-ray Absorption Fine Structure (EXAFS) results. ${ }^{32}$

\section{Results}

The as-deposited films were routinely characterized in order to quantify the Mg content, thickness and resistivity of the films (Table 1). Both $\mathrm{Cu}_{2} \mathrm{O}$ and $\mathrm{Cu}_{2} \mathrm{O}: \mathrm{Mg}$ as-deposited films presented a yellow colour under ambient light (see Figure S1 in Supporting Information). 
Table 1 General properties of as-deposited $\mathrm{Cu}_{2} \mathrm{O}$ and $\mathrm{Cu}_{2} \mathrm{O}: \mathrm{Mg}$ films for the stability study

\begin{tabular}{ccccc}
\hline Sample & $\begin{array}{c}\text { Mg/(Mg+Cu) in } \\
\text { solution }(\% \text { at })\end{array}$ & $\begin{array}{c}\text { Mg/Mg+Cu in } \\
\text { film }(\% \text { at })\end{array}$ & $\begin{array}{c}\text { Thickness } \\
(\mathbf{n m})\end{array}$ & $\begin{array}{c}\text { Resistivity } \\
(\mathbf{\Omega} . \mathbf{c m})\end{array}$ \\
\hline $\mathrm{Cu}_{2} \mathrm{O}$ & 0 & 0 & $244 \pm 10$ & $178 \pm 20$ \\
\hline $\mathrm{Cu}_{2} \mathrm{O}: \mathrm{Mg}$ & 33 & $18 \pm 1$ & $183 \pm 20$ & $80 \pm 15$ \\
\hline
\end{tabular}

The films were then cut in four different specimen and three different specimens of each film were annealed at $250{ }^{\circ} \mathrm{C}, 350{ }^{\circ} \mathrm{C}$ and $450{ }^{\circ} \mathrm{C}$ for 30 minutes in air. The temperature evolution of the $\mathrm{Cu}_{2} \mathrm{O}$ and $\mathrm{Cu}_{2} \mathrm{O}: \mathrm{Mg}$ diffraction patterns obtained by GI-XRD is presented in Figure 1. Only the diffraction peaks corresponding to the $\mathrm{Cu}_{2} \mathrm{O}$ phase are detected in the asdeposited film and in the film annealed at $250^{\circ} \mathrm{C}$ for both undoped and $\mathrm{Mg}$-doped films. When the annealing temperature increases to $350^{\circ} \mathrm{C}$, two additional diffraction peaks are clearly detected at $35.5^{\circ}$ and $38.7^{\circ}$ for the undoped thin film. They can be attributed to the (11-1) and (111) reflections of the $\mathrm{CuO}$ monoclinic phase, respectively. At the same temperature, only a small diffraction peak at $38.7^{\circ}$ attributed to the (111) $\mathrm{CuO}$ phase is detected in the $\mathrm{Mg}$-doped film. After annealing at $450^{\circ} \mathrm{C}$, the undoped film pattern is mainly composed of ten diffraction peaks associated to the $\mathrm{CuO}$ phase and weak residual peaks of $\mathrm{Cu}_{2} \mathrm{O}$ at $36.4^{\circ}, 42.3^{\circ}$ and $61.3^{\circ}$ corresponding to the (111), (200) and (220) reflections. As for the $\mathrm{Cu}_{2} \mathrm{O}: \mathrm{Mg}$ film, only three $\mathrm{CuO}$ diffraction peaks are detected although the (111) $\mathrm{Cu}_{2} \mathrm{O}$ reflection remains the most intense one. It is worth noting that this reflection has been shifted from its original and theoretical position at $36.42^{\circ}$ to $36.84^{\circ}$. This result gives evidence of a modification of the lattice parameter from $4.270 \AA$ to $4.226 \AA$. No significant shift of the (111) $\mathrm{Cu}_{2} \mathrm{O}$ reflection was observed for other samples annealed at lower temperatures. 


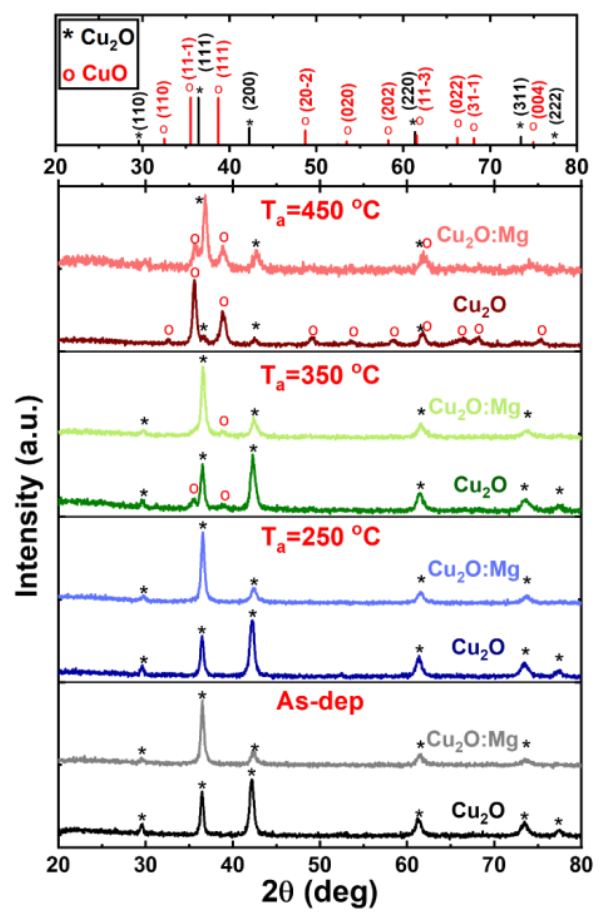

Figure $1 \mathrm{GI}$-XRD patterns of undoped and $\mathrm{Mg}$-doped $\mathrm{Cu}_{2} \mathrm{O}$ thin films deposited on glass corresponding to the as-deposited and annealed samples $\left(250,350\right.$ and $450^{\circ} \mathrm{C}$ ). The reference patterns of $\mathrm{Cu}_{2} \mathrm{O}$ (cubic, space group Pn-3m, JCPDS $n^{\circ}$ 04-007-9767) and $\mathrm{CuO}$ (monoclinic, space group C2/c, ICDD $n^{\circ}$ 00-048-1548) are shown at the top. $\mathrm{Cu}_{2} \mathrm{O}$ and $\mathrm{CuO}$ reflections are marked with ${ }^{*}$ and ${ }^{\circ}$, respectively.

Raman spectroscopy was used to clarify the early stage of the phase transformation in these sets of samples. This technique is complementary to XRD analysis as it allows a local analysis. Raman spectra of as-deposited and annealed $\mathrm{Cu}_{2} \mathrm{O}$ and $\mathrm{Cu}_{2} \mathrm{O}: \mathrm{Mg}$ thin films are shown in Figure 2. In agreement with XRD results and independently of the doping, Raman spectra of as-deposited and $250^{\circ} \mathrm{C}$ annealed films are only composed of lines characteristic of the $\mathrm{Cu}_{2} \mathrm{O}$ phase, at 109, 149, 190, 217, 298, 417, 496, 646 and $798 \mathrm{~cm}^{-1} \cdot{ }^{27}$ A decrease of the line intensity is observed for the doped film in comparison with the undoped one. After annealing at $350^{\circ} \mathrm{C}$, the Raman spectrum of the $\mathrm{Cu}_{2} \mathrm{O}: \mathrm{Mg}$ film appears unchanged whereas one additional line is barely detected at $348 \mathrm{~cm}^{-1}$ for the undoped film. It can be assigned to the $B_{g}{ }^{l}$ mode of $\mathrm{CuO}$. The CuO Raman spectrum is composed of three modes at $296 \mathrm{~cm}^{-1}\left(A_{g}\right), 350 \mathrm{~cm}^{-1}\left(B_{g}{ }^{l}\right)$ and 632 $\mathrm{cm}^{-1}\left(B_{g}{ }^{2}\right)^{33,34}$ and the peak at $350 \mathrm{~cm}^{-1}$ is the only one which can differentiate $\mathrm{CuO}$ from $\mathrm{Cu}_{2} \mathrm{O}$, since the two other ones have positions very close to $\mathrm{Cu}_{2} \mathrm{O}$ modes. After annealing at $450^{\circ} \mathrm{C}$, the spectrum of the undoped film only contains the three $\mathrm{CuO}$ modes whereas in the case of $\mathrm{Cu}_{2} \mathrm{O}: \mathrm{Mg}$, the $B_{g}{ }^{l} \mathrm{CuO}$ mode occurs in addition to the $\mathrm{Cu}_{2} \mathrm{O}$ lines, which are still present and 
form the majority of the detected Raman modes. It is to be noted that a wide fluorescence band is systematically observed in spectra of the Mg-doped films whatever the as-deposited or annealed state. It can be related to electronic defects in the films rather than to organic residues coming from the precursors, which would be decomposed at such annealing temperatures.

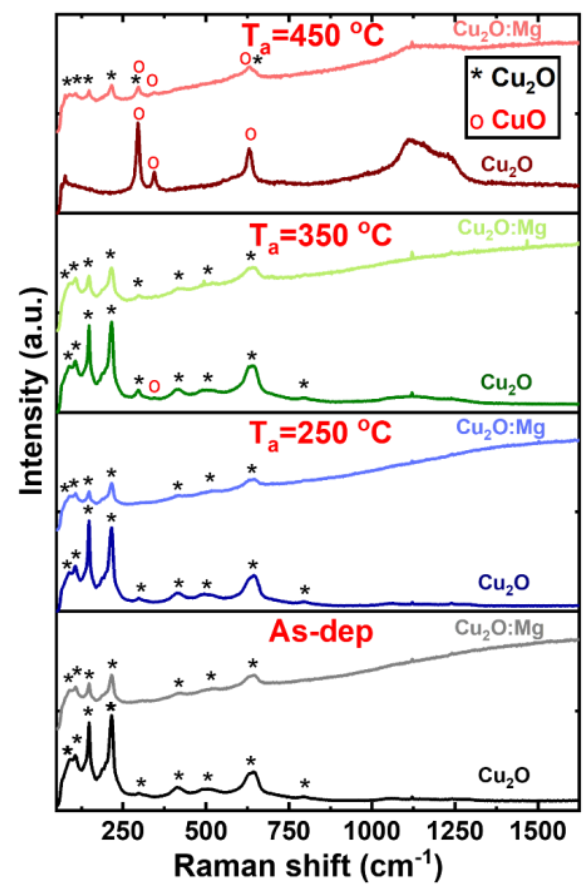

Figure 2 Raman spectra of the undoped and $\mathrm{Mg}$-doped $\mathrm{Cu}_{2} \mathrm{O}$ thin films deposited on glass corresponding to the as-deposited and annealed samples $\left(250,350\right.$ and $\left.450^{\circ} \mathrm{C}\right) . \mathrm{Cu} \mathrm{O}_{2} \mathrm{O}$ and $\mathrm{CuO}$ peaks are marked with $*$ and ${ }^{\circ}$. respectively.

In order to evaluate the doping effect on the film morphology, SEM observations of the undoped and doped as-deposited and annealed films were carried out. The SEM images corresponding to the undoped $\mathrm{Cu}_{2} \mathrm{O}$ films are shown in Figure 3 a) to d). The cross-section of the as-deposited film in the inset of Figure 3 a) shows a homogeneous layer with an average thickness of $244 \pm 10 \mathrm{~nm}$. This film observed in top-view, Figure 3 a), shows a porous surface with hardly visible grains, which is unchanged after annealing at $250^{\circ} \mathrm{C}$ (Figure $3 \mathrm{~b}$ )). The increase of the annealing temperature to $350^{\circ} \mathrm{C}$ led to film changes: small grains are now visible and the porosity seems to be reduced (Figure 3c)). The film annealed at $450^{\circ} \mathrm{C}$ shows larger grains with an average size in the $100 \mathrm{~nm}$ range, forming a rougher structure when compared 
to previous samples (Figure 3d)). The observation of the formation and growth of new grains is consistent with the formation of the $\mathrm{CuO}$ phase on top of the $\mathrm{Cu}_{2} \mathrm{O}$ thin films.

SEM micrographs of $\mathrm{Mg}$-doped $\mathrm{Cu}_{2} \mathrm{O}$ films are presented in Figure $3 \mathrm{e}$ ) to h). The crosssection of the as-deposited film in the inset of Figure 3e) shows a rougher and more irregular layer in comparison with the undoped film, with an average thickness of $183 \pm 20 \mathrm{~nm}$. This uneven morphology was also confirmed in the top view image, where a rough surface with larger grains is visible (Figure $3 \mathrm{e}$ )) and is retained after annealing at $250^{\circ} \mathrm{C}$ (Figure $3 \mathrm{f}$ )). This effect of the dopant has been already observed for $\mathrm{Sr}$-doped and $\mathrm{Mg}$-doped $\mathrm{Cu}_{2} \mathrm{O}$ thin films. ${ }^{27,29}$ When the thermal treatment is performed at $350^{\circ} \mathrm{C}$ (Figure $3 \mathrm{~g}$ )), small grains with a size smaller than $100 \mathrm{~nm}$ start to appear on the top of the original morphology, covering $26 \%$ of the film surface. The quantification was obtained by using ImageJ software (see Figure S2 in Supporting Information). The film annealed at $450^{\circ} \mathrm{C}$ shows its surface completely covered with grains of approximate size below 100nm (Figure $3 \mathrm{~h}$ )), smaller than in the undoped $\mathrm{Cu}_{2} \mathrm{O}$ films. The uniform distribution of the small grains on the film surface maintains a roughness similar to that obtained for the $\mathrm{Cu}_{2} \mathrm{O}: \mathrm{Mg}$ as-deposited thin film.

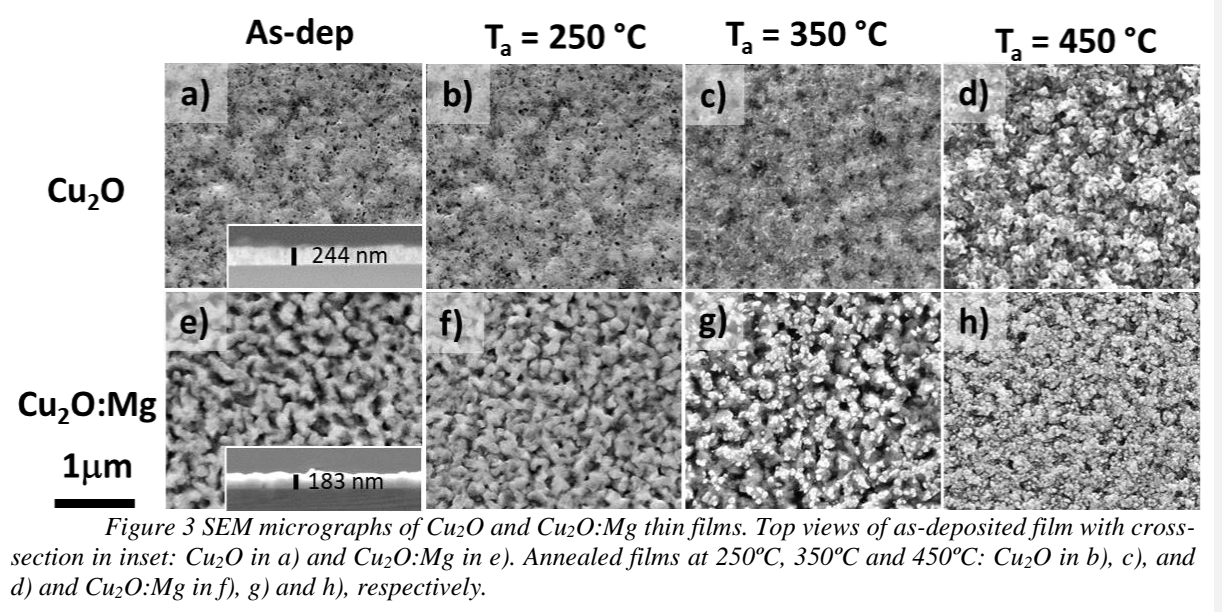

XPS was used to detect the chemical changes and determine the $\mathrm{Cu}$ oxidation state in the upper $10 \mathrm{~nm}$ of the films. As-deposited and $250{ }^{\circ} \mathrm{C}$ annealed samples were selected for this analysis in order to give an insight into the beginning of the transformation of $\mathrm{Cu}_{2} \mathrm{O}$ into $\mathrm{CuO}$. The $\mathrm{Cu}$ oxidation state was analysed by scanning the $\mathrm{Cu} 2 \mathrm{p}$ spectra without cleaning etching of the film surface. Spectra of the as-deposited and $250^{\circ} \mathrm{C}$ annealed films are presented in Figure 4. In the case of undoped films, the $\mathrm{Cu}$ doublet assigned to the $\mathrm{Cu} 2 \mathrm{p}_{3 / 2}$ and $\mathrm{Cu} 2 \mathrm{p}_{1 / 2}$ states is 
accompanied by satellites at $940-945 \mathrm{eV}$, clearly indicating the presence of $\mathrm{Cu}^{2+}$ at the film surface, ${ }^{35}$ even in the as-deposited thin films. The $\mathrm{Cu} 2 \mathrm{p}$ doublet is composed by two contributions corresponding to $\mathrm{Cu}^{+}$and $\mathrm{Cu}^{2+}$. After thermal treatment at $250^{\circ} \mathrm{C}$, the intensity of all the $\mathrm{Cu}^{2+}$ peaks increases indicating an increase of $\mathrm{CuO}$ at the film surface. The spectra obtained at the surface of the $\mathrm{Cu}_{2} \mathrm{O}: \mathrm{Mg}$ films before and after annealing are similar and contain only the doublet peaks characteristic of $\mathrm{Cu}^{+}$, i.e. two narrow peaks at $932 \mathrm{eV}$ and at $952 \mathrm{eV}$ without any satellite. ${ }^{35}$ This result confirms that the $\mathrm{CuO}$ phase is not present at the $\mathrm{Cu}_{2} \mathrm{O}: \mathrm{Mg}$ film surface even after thermal treatment at $250^{\circ} \mathrm{C}$.

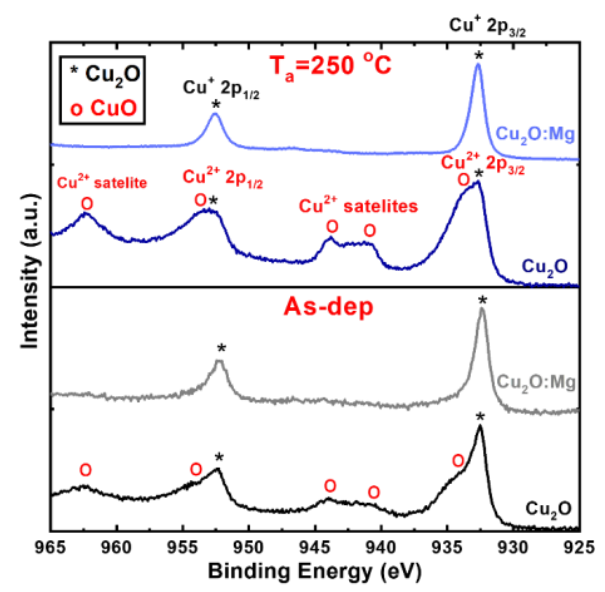

Figure $4 \mathrm{Cu} 2 \mathrm{p}$ XPS spectra obtained for the undoped and $\mathrm{Mg}$-doped $\mathrm{Cu}_{2} \mathrm{O}$ thin films deposited on glass, both as-deposited and annealed at $250^{\circ} \mathrm{C}$.

X-ray absorption spectroscopy (XAS) has been used to complete XPS results as it probes the full thickness of the films and provide an element-selective information on the atomic local environment of the atoms. XAS spectra of undoped and $\mathrm{Mg}$-doped $\mathrm{Cu}_{2} \mathrm{O}$ films, as-deposited and annealed at several temperatures, were analysed at the $\mathrm{Cu}-\mathrm{K}$ edge (8978.9 eV). Two extra samples of $\mathrm{Cu}_{2} \mathrm{O}$ and $\mathrm{Cu}_{2} \mathrm{O}: \mathrm{Mg}$ were annealed at $500{ }^{\circ} \mathrm{C}$ for 30 minutes. This temperature allows to obtain the complete oxidation of the layers and thus, $\mathrm{CuO}$ reference films for both sets of samples.

The X-ray Absorption Near Edge Structure (XANES) spectra of the films are presented in Figure $5 \mathrm{a}$ ). The edge energy position $\left(\mathrm{E}_{0}\right)$ is taken as the first maximum in the first derivative spectrum (see Figure S3 in Supporting Information). A shift of $\mathrm{E}_{0}$ from $8980.8 \mathrm{eV}$ to 8984.1 $\mathrm{eV}$ is observed with increasing annealing temperature for both groups of samples. This $\mathrm{E}_{0}$ shift arises from the modification of the $\mathrm{Cu}$ linear coordination in $\mathrm{Cu}_{2} \mathrm{O}$, similar to that reported from 
other studies in the $\mathrm{Cu}-\mathrm{O}$ system. ${ }^{36,37}$ The change in the oxidation state of the copper atom, from $\mathrm{Cu}^{+}$into $\mathrm{Cu}^{2+}$, leads to the observed $3.3 \mathrm{eV}$ shift of the edge energy position, as confirmed by experimental ${ }^{38}$ and theoretical studies. ${ }^{39}$

The Extended X-ray absorption Fine Structure (EXAFS) spectra - extracted via the standard background removal procedure - are shown in Figure 5 b). The XANES and EXAFS spectra versus the annealing temperature are identical for both $\mathrm{Cu}_{2} \mathrm{O}$ and $\mathrm{Cu}_{2} \mathrm{O}: \mathrm{Mg}$ thin films, except the $450{ }^{\circ} \mathrm{C}$ annealing step. In particular, a little deviation from $\mathrm{Cu}_{2} \mathrm{O}$ is observed in comparison with the as-deposited up to $350{ }^{\circ} \mathrm{C}$ annealed spectra while a full conversion to $\mathrm{CuO}$ occurs at $500{ }^{\circ} \mathrm{C}$ for both types of films. The $450{ }^{\circ} \mathrm{C}$ annealing step is different for $\mathrm{Cu}_{2} \mathrm{O}$ and $\mathrm{Cu}_{2} \mathrm{O}: \mathrm{Mg}$ thin films. At $450{ }^{\circ} \mathrm{C}, \mathrm{Cu}_{2} \mathrm{O}$ thin films show a full conversion to $\mathrm{CuO}$, while the $\mathrm{Mg}$ doped thin films show a mixed character. This is visible in Figure $5 \mathrm{c}$ ), where the amplitude of the Fourier Transform of the EXAFS data (FT) in the range 3.5 to $13 \AA^{-1}$ is shown for the 450 ${ }^{\circ} \mathrm{C}$ annealing step, compared to the as-deposited and the $500{ }^{\circ} \mathrm{C}$ one. The FT may be associated to an average radial distribution function around the absorbing atoms $(\mathrm{Cu})$, with the caveat that the distance scale is not correct, due to the absence of the phase correction. The first peak in the FT, corresponding to a neighbour distance between 1 and $2 \AA$, is identified as the oxygen first neighbour $\left(\mathrm{Cu}-\mathrm{O} 1^{\text {st }}\right)$ for $\mathrm{Cu}_{2} \mathrm{O}$ and $\mathrm{CuO}$. There is an increase of the peak intensity combined with a small shift to higher distances, related to the structural changes associated with the phase transformation: a higher number of $\mathrm{O}$ neighbouring atoms between the $\mathrm{Cu}_{2} \mathrm{O}$ and $\mathrm{CuO}$, changing from 2 to 4 , as well as an increase of the $\mathrm{Cu}-\mathrm{O}$ distance, from $1.85 \AA$ in $\mathrm{Cu}_{2} \mathrm{O}$ to $1.95 \AA$ in $\mathrm{CuO}$. The second peak, corresponding to a neighbour distance between 2 and $4 \AA$, is attributed to copper neighbour atoms $\left(\mathrm{Cu}-\mathrm{Cu} 1^{\text {st }}\right)$. When $\mathrm{Cu}_{2} \mathrm{O}$ transforms into $\mathrm{CuO}$, the peak splits into two parts, attributed to copper neighbours of higher order $\left(1^{\text {st }}, 2^{\text {nd }}\right.$ and $\left.3^{\text {rd }}\right)$, as well as $3^{\text {rd }}$ order $\mathrm{O}$ neighbours. In the case of $\mathrm{Mg}$-doped $\mathrm{Cu}_{2} \mathrm{O}$ film annealed at $450{ }^{\circ} \mathrm{C}$, there is an intermediate state for both peaks, $\mathrm{Cu}-\mathrm{O} 1^{\text {st }}$ and $\mathrm{Cu}-\mathrm{Cu} 1^{\text {st }}$, represented in Figure $5 \mathrm{c}$ ), which were undetected in any spectrum of the undoped $\mathrm{Cu}_{2} \mathrm{O}$ samples. Nevertheless, this is an oversimplified qualitative evaluation in order to give a simple visual interpretation of the evolution of the spectra from as-deposited $\mathrm{Cu}_{2} \mathrm{O}$ to the $500{ }^{\circ} \mathrm{C}$ annealed $\mathrm{CuO}$. By this simple approach is possible to visually compare the case at $450{ }^{\circ} \mathrm{C}$, showing differences with the $\mathrm{Mg}$ doping: $\mathrm{Cu}$ $\mathrm{O}$ group less intense and $\mathrm{Cu}-\mathrm{Cu}$ group less "split" peaks, which is a signature of the less amount of $\mathrm{CuO}$. The peaks shown in the Fourier Transform amplitude, Figure $5 \mathrm{c}$ ), are generated by the sum of the photoelectron scattering paths (single and multiple) from the absorbing $\mathrm{Cu}$ atoms, corresponding to an average ensemble of distances. 

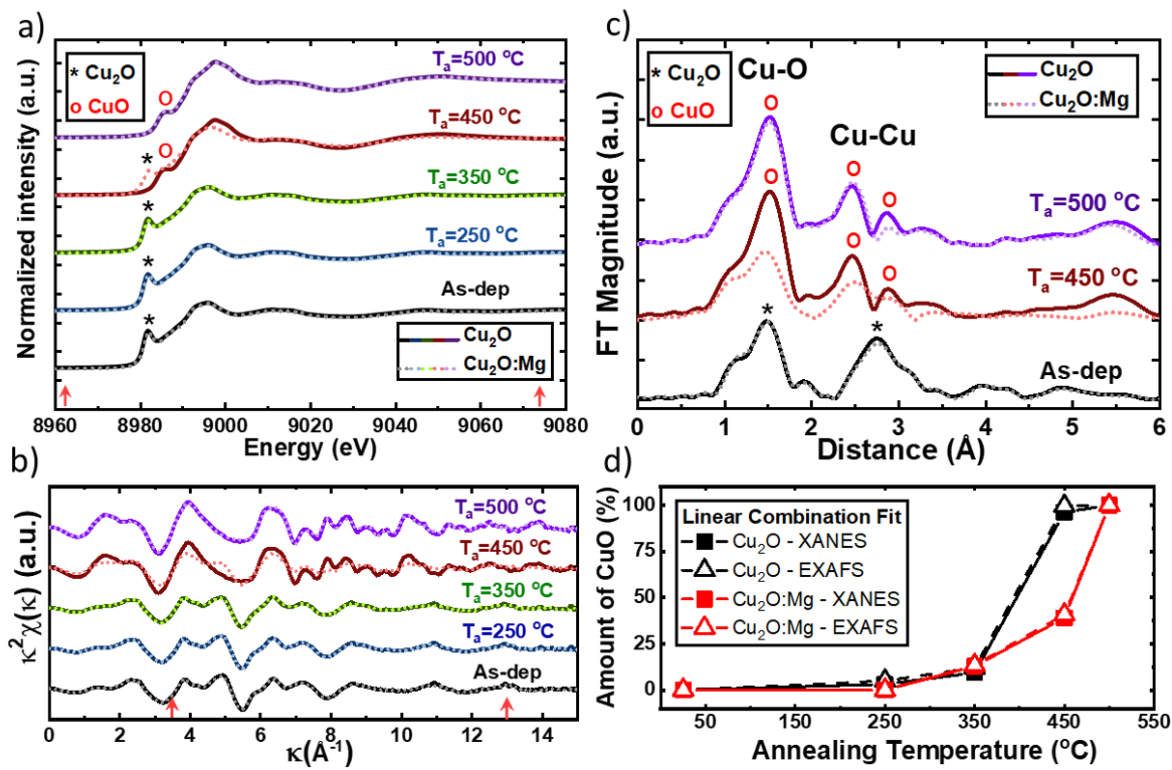

Figure $5 \mathrm{Cu}$ K-edge XAS data and linear combination fits for the undoped (solid lines) and Mg-doped $\mathrm{Cu}_{2} \mathrm{O}$ (dotted lines) thin films corresponding to the as-deposited and annealed samples (250, 350, 450 and 500 $\left.{ }^{\circ} \mathrm{C}\right)$. a) XANES region, b) $k^{2}$-weighted EXAFS spectra and c) amplitude - not phase corrected - of the Fourier transform (selected subset of data) in the k-range 3.5-13 $\AA^{-1}$. Red arrows represent the energy range and $k$-range employed for the linear combination fits. d) Results of the linear combination fits of the $\mathrm{Cu}_{2} \mathrm{O}$ and $\mathrm{CuO}$ experimental reference spectra (cf. main text).

To quantify the amount of $\mathrm{CuO}$ formed in the films during the thermal annealing, a linear combination fit (LCF) for both XANES and EXAFS spectra was performed, using as basis set the $\mathrm{Cu}_{2} \mathrm{O}$ and $\mathrm{CuO}$ reference spectra. For the $\mathrm{Cu}_{2} \mathrm{O}$ case, the undoped $\mathrm{Cu}_{2} \mathrm{O}$ asdeposited spectrum was employed as reference; while we selected the spectrum of undoped $\mathrm{Cu}_{2} \mathrm{O}$ annealed at $500{ }^{\circ} \mathrm{C}$ for $\mathrm{CuO}$ reference, due to its complete transformation into $\mathrm{CuO}$. The $\mathrm{k}^{2} \chi$ and Fourier Transform of the $\mathrm{Cu}_{2} \mathrm{O}$ and $\mathrm{CuO}$ reference spectra show a good agreement with the respective $\mathrm{Cu}_{2} \mathrm{O}$ and $\mathrm{CuO}$ simulated spectra from the each crystal structure (see Figure $\mathrm{S} 4$ in the Supporting Information). The fit range was -30 to $+80 \mathrm{eV}$ with respect to $\mathrm{E}_{0}$ for the normalized XANES, and 3.5 to $13 \AA^{-1}$ for the $k^{2}$-weighted EXAFS, i.e. $k^{2} \chi(k)$. The fits were performed using the Athena software ${ }^{40}$. The LCF method takes into account, for each $\mathrm{Cu}_{2} \mathrm{O}$ and $\mathrm{CuO}$ phase, the full multiple scattering configuration; for this reason and in this particular case, this method is superior to a simplified scattering path expansion fit. The results obtained from the XANES and EXAFS LCF are shown in Figure $5 \mathrm{~d}$ ), and the single plots of the fits with the corresponding residuals are plotted in the Supplementary Information (Figures S5 and 
S6). The combined error bars are below 1\% (smaller than the symbol size in Figure 5d). For annealing temperature up to $350{ }^{\circ} \mathrm{C}$, both films present similar quantities of $\mathrm{CuO}$, linearly increasing up to $12(1) \%$. We can observe a substantial difference in the $\mathrm{CuO}$ amount between the two films annealed at $450{ }^{\circ} \mathrm{C}$, where the undoped sample presents almost full conversion from $\mathrm{Cu}_{2} \mathrm{O}$ to the $\mathrm{CuO}$ phase, that is, $98(1) \%$. In the $\mathrm{Mg}$-doped $\mathrm{Cu}_{2} \mathrm{O}$ film, we observe a drastically lower amount of $\mathrm{CuO}$, that is, $40(1) \%$. This result agrees with the position of the edge energy in the XANES spectra.

\section{Discussion}

A detailed analysis of the results obtained in this study allowed us to provide a comprehensive model for the magnesium incorporation and the related effects on the stability of the $\mathrm{Cu}_{2} \mathrm{O}$ phase under different annealing treatments.

The direct comparison of the annealing effects on both sets of samples gives evidence of some differences in terms of growth of the $\mathrm{CuO}$ phase. The morphological analysis obtained by SEM images combined with the structural results provided by XRD, Raman, XANES and EXAFS suggests that the formation of $\mathrm{CuO}$ is associated to the formation of smaller and brighter grains at the surface. The formation of these grains takes place differently in the two samples annealed at $350{ }^{\circ} \mathrm{C}$. In the undoped film, the new grains seem to grow on the total surface of the film while in the $\mathrm{Mg}$-doped films, the $\mathrm{CuO}$ grains are only formed in places, representing around $26 \%$ of the visible surface. For the $\mathrm{Cu}_{2} \mathrm{O}: \mathrm{Mg}$ films, an annealing temperature of $450{ }^{\circ} \mathrm{C}$ is needed to obtain a morphology similar to that of the undoped sample annealed at $350{ }^{\circ} \mathrm{C}$, consisting in small grains covering completely the film surface. Moreover, the undoped $\mathrm{Cu}_{2} \mathrm{O}$ films annealed at $450^{\circ} \mathrm{C}$ show a different aspect and exhibit larger $\mathrm{CuO}$ grains, which is consistent with a higher degree of phase transformation as shown in the GI$\mathrm{XRD}$ and Raman results. We can generalize the formation of $\mathrm{CuO}$ for temperatures below $350^{\circ} \mathrm{C}$ in both undoped and $\mathrm{Mg}$-doped thin films, but with different kinetics.

The different behaviours in both sets of samples led us to identify two distinct mechanisms for the $\mathrm{CuO}$ formation. On the one hand, the undoped thin films transform into $\mathrm{CuO}$ by oxidation both at the film surface and in the bulk. At the film surface, the $\mathrm{Cu}^{+}$cations are easily oxidized into $\mathrm{Cu}^{2+}$ in contact with oxygen forming new grains of the $\mathrm{CuO}$ phase. This was confirmed by the XPS analysis, which reveals the presence of $\mathrm{Cu}^{2+}$ even in the as-deposited samples. The presence of magnesium seems to affect the surface of the $\mathrm{Cu}_{2} \mathrm{O}$ thin film even before any thermal annealing, as the $\mathrm{Cu}^{2+}$ signature in XPS spectrum is absent for the $\mathrm{Cu}_{2} \mathrm{O}: \mathrm{Mg}$ 
as-deposited thin film. Apart from the surface, the formation of split copper vacancies is required to induce the formation of $\mathrm{Cu}^{2+}$ centres and then create $\mathrm{CuO}$ nucleation centres inside the grains. The split copper vacancies, represented in Figure 6, lead to an inefficient generation of free holes due to the highly localized character of this type of defect, ${ }^{5,6}$ which later contributes to the formation of the parasitic $\mathrm{CuO}$ phase throughout the film. In the presence of $\mathrm{Mg}$, the transformation seems to start only at the film surface, at $350^{\circ} \mathrm{C}$, while simple copper vacancies (Figure 6) are the major defects created inside the film thanks to the presence of the dopant.

As suggested by Isseroff and Carter, Mg doping can prevent the formation of split vacancies for a single cation vacancy, since the divalent cation would be placed in a site similar to a split copper vacancy in the crystal structure. ${ }^{6}$ This fact seems to be confirmed by the resilience of $\mathrm{Cu}_{2} \mathrm{O}$ to preserve its cubic structure. The inhibition to create split vacancies would reduce the $\mathrm{CuO}$ parasitic centres inside the film, this being the main mechanism for the phase transformation during the annealing stages.

Additionally, in the $\mathrm{Cu}_{2} \mathrm{O}: \mathrm{Mg}$ thin film annealed at $450{ }^{\circ} \mathrm{C}$, a change in lattice parameters was observed by XRD. This suggests structural modifications in the $\mathrm{Cu}_{2} \mathrm{O}$ crystal structure resulting in the formation of a new type of defect in the film. One possible defect is a clustering of a second simple copper vacancy with the $\mathrm{Mg}$ atom in a tetrahedral position, $\left[M g_{i}\right.$ $\left.-2 \cdot V_{C u}\right]^{-}$, which has been proposed by Isseroff and Carter. ${ }^{6}$ Still, the nature of copper vacancies level is yet to be fully understood. A representation of both $\mathrm{Cu}_{2} \mathrm{O}$ defects is shown in Figure 6, as well as the suggested $\left[M g_{i}-2 \cdot V_{C u}\right]^{-}$complex.

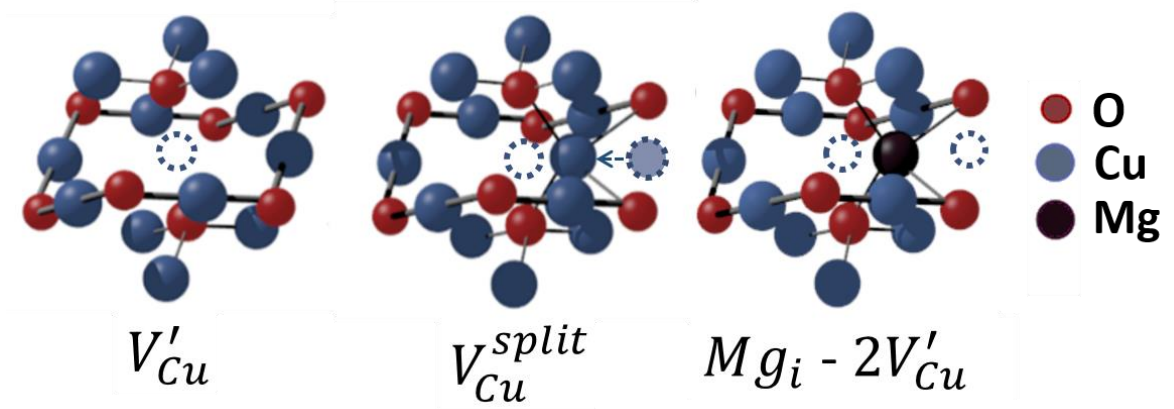

Figure 6 Representation of a single copper vacancy $\left(V_{C u}^{\prime}\right)$, a split copper vacancy $\left(V_{C u}^{\text {split }}\right)$ and a magnesium incorporation in a tetrahedral site $\left[\mathrm{Mg}_{i}-2 \cdot \mathrm{V}_{\mathrm{Cu}}\right]^{-}$. Copper atoms are represented by blue circles, oxygen as red ones and magnesium as black ones. 


\section{Conclusion}

Post-deposition annealing treatments in oxidizing conditions are commonly performed on $\mathrm{Cu}_{2} \mathrm{O}$ thin films to enhance electrical and optical properties; nevertheless, a parasitic $\mathrm{CuO}$ phase usually starts to be formed in the films at $300{ }^{\circ} \mathrm{C}$. The presence of the $\mathrm{Mg}$ dopant in the films has a substantial impact on the stability of the $\mathrm{Cu}_{2} \mathrm{O}$ phase under these oxidizing conditions, as revealed by this study. The formation of the $\mathrm{CuO}$ phase is indeed delayed in the $\mathrm{Cu}_{2} \mathrm{O}: \mathrm{Mg}$ thin films when submitted to similar annealing conditions in comparison with the undoped films. This is due to distinct formation rates of the $\mathrm{CuO}$ phase in the undoped and doped films. As suggested by Isseroff and Carter, divalent cation doping such as $\mathrm{Mg}^{2+}$, can prevent the formation of split copper vacancies, since the cation would be placed in a position similar to a split copper vacancy in the crystal structure. As a consequence, the reduction of split copper vacancies leads to a lower concentration of $\mathrm{CuO}$ nucleation centres, which inhibit the formation of the parasitic phase in the bulk of the film.

\section{Supporting Information.}

Optical appearance of undoped and $\mathrm{Mg}$-doped $\mathrm{Cu}_{2} \mathrm{O}$ thin films (Figure S1). SEM micrographs of $\mathrm{Mg}$-doped $\mathrm{Cu}_{2} \mathrm{O}$ thin films on glass annealed at $350^{\circ} \mathrm{C}$ (Figure $\mathrm{S} 2$ ). Determination of E0 in all spectra of undoped and $\mathrm{Mg}$-doped $\mathrm{Cu} 2 \mathrm{O}$ thin films on glass (Figure $\mathrm{S} 3$ ).Fitting of EXAFS reference spectra: $\mathrm{Cu}_{2} \mathrm{O}$ for as-deposited intrinsic thin film and $\mathrm{CuO}$ obtained by oxidation of $\mathrm{Cu}_{2} \mathrm{O}$ at $500^{\circ} \mathrm{C}$ during 30 minutes (Figure S4). List of EXAFS parameters obtained from fitting of reference spectra: $\mathrm{Cu}_{2} \mathrm{O}$ for as-deposited intrinsic thin film and $\mathrm{CuO}$ obtained by oxidation of $\mathrm{Cu}_{2} \mathrm{O}$ at $500^{\circ} \mathrm{C}$ during 30 minutes (Table S1). Linear combination fits and correspondent residuals XAS spectra of $\mathrm{Cu}_{2} \mathrm{O}$ and $\mathrm{Cu}_{2} \mathrm{O}: \mathrm{Mg}$ thin films (Figure S5 and S6)

\section{Acknowledgements}

Financial support by the IDS-FunMat scholarship selected under the program "ERASMUS MUNDUS II 2009-2013" is gratefully acknowledged. N. D. N. acknowledges the financial support by the Université de Liège, Fonds Spéciaux de la Recherche (project FSRC13/77 , the F.R.S-FNRS (project J.0119.14) and European Joint Doctorate FUNMAT (H2020MSCA-ITN-2014, Project ID 641640). This project was financially supported by "Carnot Energies du Futur" (SOLAROX project). This work benefited from the facilities and expertise of the OPE)N(RA characterization platform of FMNT (FR 2542, fmnt.fr) supported by CNRS, Grenoble INP and UGA. We thank Synchrotron ESRF for general facilities. The experiment at the FAME (BM30B) beamline, proposal number 30-02-1122, benefited from the French 
beamtime allocation via the SOLEIL committee. The authors would like to warmly thank Hervé Roussel for the grazing incidence X-ray diffraction measurements.

\section{References}

(1) Minami, T.; Nishi, Y.; Miyata, T. $\mathrm{Cu}_{2} \mathrm{O}$-Based Solar Cells Using Oxide Semiconductors. J. Semicond. 2016, 37 (1). https://doi.org/10.1088/1674-4926/37/1/014002.

(2) Nandy, S.; Banerjee, A.; Fortunato, E.; Martins, R. A Review on $\mathrm{Cu}_{2} \mathrm{O}$ and $\mathrm{Cu}$-Based pType Semiconducting Transparent Oxide Materials: Promising Candidates for New Generation Oxide Based Electronics. Rev. Adv. Sci. Eng. 2013, 2 (4), 273-304. https://doi.org/10.1166/rase.2013.1045.

(3) Biccari, F.; Malerba, C.; Mittiga, A. Defects and Doping in $\mathrm{Cu}_{2} \mathrm{O}$ : General Properties and Applications. 2009, No. 688774, 1-28. https://doi.org/10.1016/00381098(70)90325-X.

(4) Scanlon, D. O.; Walsh, A.; Watson, G. W. Understanding the P-Type Conduction Properties of the Transparent Conducting Oxide $\mathrm{CuBO}_{2}$ : A Density Functional Theoryanalysis. Chem. Mater. 2009, $21 \quad$ (19), 4568-4576. https://doi.org/10.1021/cm9015113.

(5) Scanlon, D. O.; Morgan, B. J.; Watson, G. W.; Walsh, A. Acceptor Levels in P-Type $\mathrm{Cu}_{2} \mathrm{O}$ : Rationalizing Theory and Experiment. Phys. Rev. Lett. 2009, 103 (9), 1-4. https://doi.org/10.1103/PhysRevLett.103.096405.

(6) Isseroff, L. Y.; Carter, E. A. Electronic Structure of Pure and Doped Cuprous Oxide with Copper Vacancies: Suppression of Trap States. Chem. Mater. 2013, 25 (3), 253-265. https://doi.org/10.1021/cm3040278.

(7) Nolan, M.; Elliott, S. D. The P-Type Conduction Mechanism in $\mathrm{Cu}_{2} \mathrm{O}$ : A First Principles Study. Phys. Chem. Chem. Phys. 2006, 8 (45), 5350-5358. https://doi.org/10.1039/b611969g.

(8) Figueiredo, V.; Elangovan, E.; Gonçalves, G.; Barquinha, P.; Pereira, L.; Franco, N.; Alves, E.; Martins, R.; Fortunato, E. Effect of Post-Annealing on the Properties of Copper Oxide Thin Films Obtained from the Oxidation of Evaporated Metallic Copper. Appl. Surf. Sci. $\quad \mathbf{2 0 0 8 ,} 254 \quad$ (13), $3949-3954$. https://doi.org/10.1016/j.apsusc.2007.12.019. 
(9) Wang, Y.; Miska, P.; Pilloud, D.; Horwat, D.; Mücklich, F.; Pierson, J. F. Transmittance Enhancement and Optical Band Gap Widening of $\mathrm{Cu}_{2} \mathrm{O}$ Thin Films after Air Annealing. J. Appl. Phys. 2014, 115 (7), 2-7. https://doi.org/10.1063/1.4865957.

(10) Johan, M. R.; Suan, M. S. M.; Hawari, N. L.; Ching, H. A. Annealing Effects on the Properties of Copper Oxide Thin Films Prepared by Chemical Deposition. Int. J. Electrochem. Sci. 2011, 6 (12), 6094-6104. https://doi.org/10.1088/0268$1242 / 20 / 5 / 012$.

(11) Eisermann, S.; Kronenberger, A.; Laufer, A.; Bieber, J.; Haas, G.; Lautenschläger, S.; Homm, G.; Klar, P. J.; Meyer, B. K. Copper Oxide Thin Films by Chemical Vapor Deposition: Synthesis, Characterization and Electrical Properties. Phys. Status Solidi 2012, 209 (3), 531-536. https://doi.org/10.1002/pssa.201127493.

(12) Wang, J.; Li, C.; Zhu, Y.; Boscoboinik, J. A.; Zhou, G. Insight into the Phase Transformation Pathways of Copper Oxidation: From Oxygen Chemisorption on the Clean Surface to Multilayer Bulk Oxide Growth. J. Phys. Chem. C 2018, 122, 2651926527. https://doi.org/10.1021/acs.jpcc.8b09145.

(13) Meyer, B. K.; Polity, A.; Reppin, D.; Becker, M.; Hering, P.; Klar, P. J.; Sander, T.; Reindl, C.; Benz, J.; Eickhoff, M.; et al. Binary Copper Oxide Semiconductors: From Materials towards Devices. Phys. Status Solidi 2012, 249 (8), 1487-1509. https://doi.org/10.1002/pssb.201248128.

(14) Camacho-Espinosa, E.; Rimmaudo, I.; Riech, I.; Mis-Fernández, R.; Peña, J. L. Stability of Sputter Deposited Cuprous Oxide $\left(\mathrm{Cu}_{2} \mathrm{O}\right)$ Subjected to Ageing Conditions for

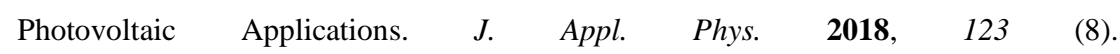
https://doi.org/10.1063/1.5017538.

(15) Deuermeier, J.; Wardenga, H. F.; Morasch, J.; Siol, S.; Nandy, S.; Calmeiro, T.; Martins, R.; Klein, A.; Fortunato, E. Highly Conductive Grain Boundaries in Copper Oxide Thin Films. J. Appl. Phys. 2016, 119 (23). https://doi.org/10.1063/1.4954002.

(16) Deuermeier, J.; Liu, H.; Rapenne, L.; Calmeiro, T.; Renou, G.; Martins, R.; MuñozRojas, D.; Fortunato, E. Visualization of Nanocrystalline $\mathrm{CuO}$ in the Grain Boundaries of $\mathrm{Cu}_{2} \mathrm{O}$ Thin Films and Effect on Band Bending and Film Resistivity. APL Mater. 2018, 6 (9), 096103. https://doi.org/10.1063/1.5042046.

(17) Rehman, S.; Hur, J. H.; Kim, D. K. Resistive Switching in Solution-Processed Copper 
Oxide $\left(\mathrm{Cu}_{\mathrm{x}} \mathrm{O}\right)$ by Stoichiometry Tuning. J. Phys. Chem. C 2018, 122 (20), 11076-11085. https://doi.org/10.1021/acs.jpcc.8b00432.

(18) Chatterjee, S.; Saha, S. K.; Pal, A. J. Formation of All-Oxide Solar Cells in Atmospheric Condition Based on $\mathrm{Cu}_{2} \mathrm{O}$ Thin-Films Grown through SILAR Technique. Sol. Energy Mater. Sol. Cells 2016, 147, 17-26. https://doi.org/10.1016/j.solmat.2015.11.045.

(19) Nishi, Y.; Miyata, T.; Minami, T. The Impact of Heterojunction Formation Temperature on Obtainable Conversion Efficiency in $\mathrm{N}-\mathrm{ZnO} / \mathrm{p}-\mathrm{Cu}_{2} \mathrm{O}$ Solar Cells. Thin Solid Films 2013, 528, 72-76. https://doi.org/10.1016/j.tsf.2012.09.090.

(20) Zang, Z. Efficiency Enhancement of $\mathrm{ZnO} / \mathrm{Cu} 2 \mathrm{O}$ Solar Cells with Well Oriented and Micrometer Grain Sized Cu2O Films. Appl. Phys. Lett. 2018, 112 (4), 42106.

(21) Yu, L.; Xiong, L.; Yu, Y. $\mathrm{Cu}_{2} \mathrm{O}$ Homojunction Solar Cells: F-Doped N-Type Thin Film and Highly Improved Efficiency. J. Phys. Chem. C 2015, 119 (40), 22803-22811. https://doi.org/10.1021/acs.jpcc.5b06736.

(22) Minami, T.; Miyata, T.; Nishi, Y. Relationship between the Electrical Properties of the $\mathrm{N}-\mathrm{Oxide}$ and $\mathrm{p}-\mathrm{Cu}_{2} \mathrm{O}$ Layers and the Photovoltaic Properties of $\mathrm{Cu}_{2} \mathrm{O}$-Based Heterojunction Solar Cells. Sol. Energy Mater. Sol. Cells 2016, 147, 85-93. https://doi.org/10.1016/j.solmat.2015.11.033.

(23) Tadatsugu, M.; Yuki, N.; Toshihiro, M. Efficiency Enhancement Using a $\mathrm{Zn}_{1-\mathrm{x}} \mathrm{Ge}_{\mathrm{x}} \mathrm{O}$ Thin Film as an n-Type Window Layer in $\mathrm{Cu}_{2} \mathrm{O}$-Based Heterojunction Solar Cells. Appl. Phys. Express 2016, 9 (5), 52301.

(24) Minami, T.; Nishi, Y.; Miyata, T. High-Efficiency $\mathrm{Cu}_{2} \mathrm{O}$-Based Heterojunction Solar Cells Fabricated Using a $\mathrm{Ga}_{2} \mathrm{O}_{3}$ Thin Film as N-Type Layer. Appl. Phys. Express 2013, 6 (4), 044101. https://doi.org/10.7567/APEX.6.044101.

(25) Malerba, C.; Azanza Ricardo, C. L.; Dincau, M.; Biccari, F.; Scardi, P.; Mittiga, A. Nitrogen Doped $\mathrm{Cu}_{2} \mathrm{O}$ : A Possible Material for Intermediate Band Solar Cells? Sol. Energy Mater. Sol. Cells 2012, 105, 192-195. https://doi.org/10.1016/j.solmat.2012.06.017.

(26) Zang, Z.; Nakamura, A.; Temmyo, J. Single Cuprous Oxide Films Synthesized by Radical Oxidation at Low Temperature for PV Application. 2013, 21 (9), 3352-3358. https://doi.org/10.1364/OE.21.011448. 
(27) Bergerot, L.; Jiménez, C.; Chaix-Pluchery, O.; Rapenne, L.; Deschanvres, J.-L. Growth and Characterization of Sr-Doped $\mathrm{Cu}_{2} \mathrm{O}$ Thin Films Deposited by Metalorganic Chemical Vapor Deposition. Phys. Status Solidi 2015, 212 (8), 1735-1741. https://doi.org/10.1002/pssa.201431750.

(28) Brochen, S.; Bergerot, L.; Favre, W.; Resende, J.; Jiménez, C.; Deschanvres, J.-L.; Consonni, V. Effect of Strontium Incorporation on the P-Type Conductivity of $\mathrm{Cu}_{2} \mathrm{O}$ Thin Films Deposited by Metal-Organic Chemical Vapor Deposition. J. Phys. Chem. C 2016, 120 (31), 17261-17267. https://doi.org/10.1021/acs.jpcc.6b05479.

(29) Resende, J.; Jiménez, C.; Nguyen, N. D.; Deschanvres, J.-L. Magnesium-Doped Cuprous Oxide $\left(\mathrm{Mg}: \mathrm{Cu}_{2} \mathrm{O}\right)$ Thin Films as a Transparent p-Type Semiconductor. Phys. Status Solidi 2016, 7, 1-7. https://doi.org/10.1002/pssa.201532870.

(30) Nolan, M.; Elliott, S. D. Tuning the Transparency of $\mathrm{Cu}_{2} \mathrm{O}$ with Substitutional Cation Doping. Chem. Mater. 2008, 20 (17), 5522-5531. https://doi.org/10.1021/cm703395k.

(31) Kardarian, K.; Nunes, D.; Maria Sberna, P.; Ginsburg, A.; Keller, D. A.; Vaz Pinto, J.; Deuermeier, J.; Anderson, A. Y.; Zaban, A.; Martins, R.; et al. Effect of Mg Doping on $\mathrm{Cu}_{2} \mathrm{O}$ Thin Films and Their Behavior on the $\mathrm{TiO}_{2} / \mathrm{Cu}_{2} \mathrm{O}$ Heterojunction Solar Cells. Sol. Energy Mater. Sol. Cells 2016, 147, 27-36. https://doi.org/10.1016/j.solmat.2015.11.041.

(32) Xpsfitting.com. $\quad \mathrm{Cu}(0): \quad \mathrm{Cu}(\mathrm{II}) \quad$ or $\quad \mathrm{Cu}(\mathrm{I}): \mathrm{Cu}(\mathrm{II}) \quad$ Calculations http://www.xpsfitting.com/2012/01/cu0cuii-or-cuicuii-calculations.html (accessed Aug 21, 2017).

(33) Goldstein, H. F.; Dai-sik, K.; Peter, Y. Y.; Bournet, L. C. Raman Study of CuO Single Crystals. Phys. Rev. B 1990, 41 (10).

(34) Guha, S.; Peebles, D.; Wieting, T. J. Zone-Center $(\mathrm{Q}=0)$ Optical Phonons in CuO Studied by Raman and Infrared Spectroscopy. Phys. Rev. B 1991, 43 (16), 13092-13101. https://doi.org/10.1103/PhysRevB.43.13092.

(35) Morales, J.; Barranco, A.; Caballero, A.; Holgado, J. P.; Gonza, a R. Interface Effects for $\mathrm{Cu}, \mathrm{CuO}$, and $\mathrm{Cu}_{2} \mathrm{O}$ Deposited on $\mathrm{SiO}_{2}$ and $\mathrm{ZrO}_{2}$. XPS Determination of the Valence State of Copper in $\mathrm{Cu} / \mathrm{SiO}_{2}$ and $\mathrm{Cu} / \mathrm{ZrO}_{2}$ Catalysts. J. Phys. Chem. B 2002, 106, 6921-6929. https://doi.org/10.1021/jp014618m.

(36) Kim, J. Y.; Rodriguez, A.; Hanson, J. C.; Frenkel, A. I.; Lee, P. L. Reduction of CuO 
and $\mathrm{Cu}_{2} \mathrm{O}$ with $\mathrm{H}_{2}$ : $\mathrm{H}$ Embedding and Kinetic Effects in the Formation of Suboxides. 2003, 10684-10692.

(37) Tolentino, H.; Medarde, M.; Fontaine, A.; Baudelet, F.; Dartyge, E.; Guay, D.; Tourillon, G. Anisotropy of the Core-Hole Relaxation in x-Ray-Absorption Spectroscopy as Probed in Square Planar Cuprates. Phys. Rev. B 1992, 45 (14), 8091-8096. https://doi.org/10.1103/PhysRevB.45.8091.

(38) Akeyama, K.; Kuroda, H.; Kosugi, N. Cu K-Edge \{XANES $\}$ and Electronic Structure of Trivalent, Divalent, and Monovalent Cu Oxides. Jpn. J. Appl. Phys. 1993, 32 (S2), 98. https://doi.org/10.7567/jjaps.32s2.98.

(39) Rudolph, J.; Jacob, C. R. Revisiting the Dependence of Cu K - Edge X - Ray Absorption Spectra on Oxidation State and Coordination Environment. Inorg. Chem. 2018, 57, 10591-10607. https://doi.org/10.1021/acs.inorgchem.8b01219.

(40) Ravel, B.; Newville, M. ATHENA, ARTEMIS, HEPHAESTUS: Data Analysis for XRay Absorption Spectroscopy Using IFEFFIT. J. Synchrotron Radiat. 2005, 12 (4), $537-$ 541.

\section{TOC Graphic}

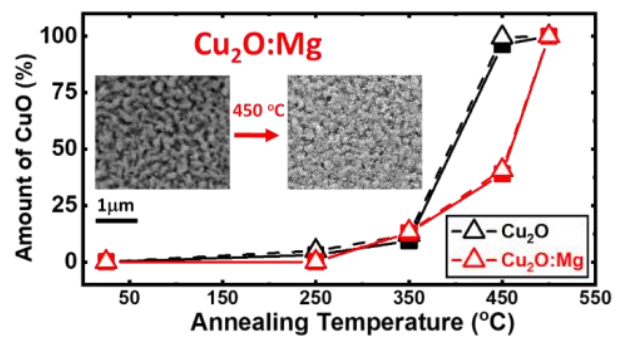

